\title{
金属溶液の安定性と濃度ゆらぎ
}

下 地 光 雄*

1. まえがき

熱力学的平衡状態はいくつかの熱力学的関数によって 完全に記述される. 微視的にはこれらの関数はその系を 構成する粒子の集団の物理量の平均值であり，個々の粒 子からの寄与は種々の值をとって分布し, ゆらいでい る。このゆらぎの問題は確率論に拈けるモーメントその 他の量を用いて定量的に論ずることができる．ある変数 $X$ の值の分布を考えるとき, その平均值 $\langle X\rangle$ は 1 次 のモーメントであり, 自乗の平均值 $\left\langle X^{2}\right\rangle$ は 2 次のモ 一メントである，そして平均値からの偏差の自乗の平均 $\left\langle(\Delta X)^{2}\right\rangle=\left\langle(X-\langle X\rangle)^{2}\right\rangle=\left\langle X^{2}\right\rangle-\langle X\rangle^{2}$

は分布の幅の尺度を示す量であり, 分散量 (variance) と 呼ばれる. その平方根 $\sqrt{\langle\Delta X)^{2}>}$ が標準偏差であるこ とはいらまでもない。

2 成分溶液の濃度を考えてみよ5。このときの変数 $X$ として成分 1 のモル分率 $x_{1}$ をるる, その分散量は (1) に従って $\left\langle\left(\Delta x_{1}\right)^{2}\right\rangle$ と書ける. 十数年前, Bhatia とThornton ${ }^{(1)}$ T, Einstein のゆらぎの理論を用いてこ の濃度のゆらぎを示す量が

$$
\left\langle\left(\Delta x_{1}\right)^{2}\right\rangle=\frac{x_{2} k_{\mathrm{B}} T}{N\left(\partial \mu_{1} / \partial x_{1}\right) T, p}=\frac{k_{\mathrm{B}} T}{\left(\partial^{2} G / \partial x_{1}^{2}\right)_{T, p}}
$$

を満足することを示した． $x_{2}$ は成分 2 のモル分率， $k_{\mathrm{B}}$ は Boltzmann 定数, $T$ は温度, $p$ は圧力, $N$ はこの系 の全粒子数, $\mu_{1}$ は成分 1 の化学ポテンシャル (粒子 1 個 当り)，Gは系の Gibbs 自由エネルギーである. この式 は2. で示すように大正準集合 (grand canonical ensemble) の手法によって厳密に導ける結果でもある。ここで 化学ポテンシャル $\mu_{1}$ は純成分の場合の値を $\mu_{1}^{0}$, 活量係 数を $f_{1}$ と劣くことにより

* 北海道大学教授; 理学部化学第二学科

Stability and Concentration Fluctuations in Metallic Solutions : Mitsuo Shimoji (Faculty of Sci. Hokkaido Univ. Sapporo)

Keywords : stability, concentration fluctuations, interdiffusion coefficient, structure factor, metallic solutions, rapid solidifica. 1986 年 6 月 5 日受理

$$
\mu_{1}=\mu_{1}^{0}+k_{\mathrm{B}} T \ln f_{1} x_{1}
$$

と書けることに注意すると， $\left\langle\left(\Delta x_{1}\right)^{2}\right\rangle$ の大きさは $1 / N$ の程度であることがわかる．巨視的な系であれば $N$ の 値は極めて大きいので, 平均濃度からのずれを示す分散 量そのものは極めて小さく, 実際上その効果を無視して 濃度を記述しても差し支えない。しかし， $N$ を乗じて得 られる $N<\left(\Delta x_{1}\right)^{2}>$ は, 次の例に見るように溶液の性質 を示す重要な量の 1 つである。

まず第 1 に(2)において $N<\left(\Delta x_{1}\right)^{2}>$ は注目する 2 成 分溶液の安定度 (3. 参照) を示す $\left(\partial \mu_{1} / \partial x_{1}\right)_{T, p}$ に逆比例し ていることに注意されたい.安定度が増せば， $N\left\langle\left(\Delta x_{1}\right)^{2}\right\rangle$ は減少し, 逆の場合は増加する。特に 2 液相分離の臨界 点の近くでは $\left(\partial \mu_{1} / \partial x_{1}\right)_{T, p}$ の值は零に近くなり濃度のゆ らぎが極めて大きくなる，溶液の安定性を論ずること は，濃度ゆらぎの大小を論ずることに他ならない。

次いで相互拡散係数 $D_{12}$ との関連に注目しょう。よく 知られているように(2)-(5) $D_{12}$ は

$$
D_{12}=\left(1+\partial \ln f_{1} / \partial \ln x_{1}\right) D_{12}^{\text {Id }}
$$

と書ける。 $D_{12}^{\mathrm{Id}}$ は対象とする系を理想溶液とみなしたと きの相互拡散係数である。(2),(3)からこの式は

$$
D_{12}=\frac{x_{1} x_{2}}{\left.N<\left(\Delta x_{1}\right)^{2}\right\rangle} D_{12}^{\mathrm{Id}}
$$

と書けることが容易にわかる，あるいは後述の式(42)で 定義される $S_{c c}(0)$ を用いると

$$
D_{12}=x_{1} x_{2} D_{12}^{\mathrm{Id}} / S_{c c}(0)
$$

ともあらわせる(2).（5)，(5') は濃度ゆらぎが拡散過程 で如何に重要な役割を演じているかを具体的に示してい る. 実際の金属溶液の拡散に和けるこの熱力学的因子す なわち濃度ゆらぎの影響に関する実験的検討については 丹羽ら ${ }^{(6)}$ によるもを始め，いくつかの研究 ${ }^{(7)}$ が報告さ れている.

この小稿の目的は, 溶液のゆらぎと安定性についての 基礎概念を説明し，金属溶液の研究に打けるそれらの重 要性を指摘することである．2.では大正準集合を用いた 式 (2)の厳密な導出, 3. では溶液の安定性とゆらぎの理 論との関連, 4.では静的, 動的構造因子の定義とその特 
徵をそれぞれ述べる．5.では液体合金のモデルと濃度ゆ らぎの関係を概観し，最後に6. で平衡から著しくはず れた非平衡の場合の金属溶液の濃度ゆらぎの問題点につ いて簡単に触れる。

\section{2. 濃度ゆらぎの平衡統計熱力学}

まず濃度ゆらぎと粒子数ゆらぎの関係を考える，2成 分系の成分 1,2 の粒子数を $N_{1}, N_{2}$ とするとモル分率 $x_{1}$ は

$$
x_{1}=N_{1} /\left(N_{1}+N_{2}\right)
$$

と書けるから， $x_{1}$ は $N_{1}, N_{2}$ の関数である. 従ってその 全微分は

$$
\begin{aligned}
\mathrm{d} x_{1} & =\left(\partial x_{1} / \partial N_{1}\right)_{N_{2}} \mathrm{~d} N_{1}+\left(\partial x_{1} / \partial N_{2}\right)_{N_{1}} \mathrm{~d} N_{2} \\
& =\left\{N_{2} /\left(N_{1}+N_{2}\right)^{2}\right\} \mathrm{d} N_{1}-\left\{N_{1} /\left(N_{1}+N_{2}\right)^{2}\right\} \mathrm{d} N_{2}
\end{aligned}
$$

のよらにあらわされる。 $\mathrm{d} x_{1}$ を有限量 $\Delta x_{1}$ で書くと $(7)$ 加

$$
\Delta x_{1}=N^{-1}\left(x_{2} \Delta N_{1}-x_{1} \Delta N_{2}\right)
$$

を得る。ただし

$$
\Delta N_{1}=N_{1}-\left\langle N_{1}\right\rangle, \Delta N_{2}=\Delta N_{2}-\left\langle N_{2}\right\rangle
$$

と定義する. $\left\langle N_{\alpha}>\right.$ は成分 $\alpha$ の粒子数の平均值である.

これより分散量 $\left\langle\left(\Delta x_{1}\right)^{2}\right\rangle$ は

$$
\begin{aligned}
\left\langle\left(\Delta x_{1}\right)^{2}\right\rangle= & N^{-2}\left\{x_{2}^{2}<\left(\Delta N_{1}\right)^{2}+x_{1}^{2}<\left(\Delta N_{2}\right)^{2}\right\rangle \\
& \left.\left.-2 x_{1} x_{2}<\Delta N_{1} \Delta N_{2}\right\rangle\right\}
\end{aligned}
$$

と書け，〈( $\left\langle x_{1}\right)^{2}>$ は粒子数のゆらぎ $\left(\Delta N_{\alpha} \Delta N_{\beta}>\right.$ がわ かればただちに求まることになる。

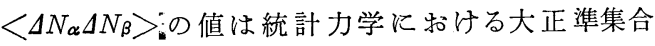
(grand canonical ensemble)の方法を用いると容易に計 算できる。温度 $T$, 体積 $V$ 一定の条件下では

$$
\left\langle\Delta N_{\alpha} \Delta N_{\beta}\right\rangle=k_{\mathrm{B}} T\left(\partial\left\langle N_{\alpha}\right\rangle / \partial \mu_{\beta}\right)_{T, V\left\{\mu_{\alpha} \neq \beta\right\}}
$$

を得る ${ }^{(8)-(10)}$. ここで添字 $\left\{\mu_{\alpha \neq \beta}\right\}$ は $\beta$ 以外の成分の化 学ポテンシャルを一定に保つことを意味しており，(11） は通常の実験条件としては不便な形であらわされてい る.これを $\left\{N_{\alpha \neq \beta}\right\}$ すなわち $\beta$ 以外の成分の粒子数が一 定といら便利な条件に変更すると, 次式が得られる ${ }^{(9)}$.

$$
\left\langle\Delta N_{\alpha} \Delta N_{\beta}\right\rangle=k_{\mathrm{B}} T|A|_{\alpha \beta} /|A|
$$

ここで $|A|$ は行列式でその要素は

$$
A_{\alpha \beta \beta}=\left(\frac{\partial \mu_{\alpha}}{\partial N_{\beta}}\right)_{T, V,\left\{N_{\alpha} \neq \beta\right\}}=\left(\frac{\partial \mu_{\alpha}}{\partial N_{\beta}}\right)_{T p,\left\{N_{\alpha} \neq \beta\right\}}+\frac{v_{\alpha} v_{\beta}}{V \kappa_{T}}
$$

である. $|A|_{\alpha \beta}$ は $A_{\alpha \beta}$ の余因数， $\kappa_{T}$ は等温圧縮率， $v_{\alpha}$ は成分 $\alpha$ の部分原子体積である. 当然 $V / N=\sum_{\alpha} x_{\alpha} v_{\alpha}$ が成り立つ。

式(12)を用いると式(10)は

$$
\begin{aligned}
N^{2}\left\langle\left(\Delta x_{1}\right)^{2}\right\rangle & =k_{\mathrm{B}} T\left\{x_{2}^{2} A_{22}+x_{1}^{2} A_{11}\right. \\
& \left.+x_{1} x_{2}\left(A_{12}+A_{21}\right)\right\} /|A|
\end{aligned}
$$

となる。 $\partial \mu_{\alpha} / \partial N_{\beta}$ をル分率の微分に変換し, Gibbs-
Duhem の関係を用いることにより分母の行列式は

$$
|A|=A_{11} A_{22}-A_{12} A_{21}=\frac{V}{N^{3} x_{2} \kappa T}\left(\frac{\partial \mu_{1}}{\partial x_{1}}\right)_{T, p}
$$

と計算される。また（14）の分子の中括弧の中は同様の 手続きで

$$
x_{2}^{2} A_{22}+x_{1}^{2} A_{11}+2 x_{1} x_{2} A_{12}=V /\left(N^{2} \kappa_{T}\right)
$$

となる。（15)，(16)を(14)に入れることにより，濃度ゆ らぎと熱力学的関数の関係を示す前述の式 (2) と同一の 結果が得られる。

密度ゆらぎ(あたえられた体積中での粒子数のゆらぎ) $\left\langle(\Delta N)^{2}\right\rangle$ および密度・濃度ゆらぎ(粒子数と濃度のゆ らぎの相関 $\left.)<\Delta N \Delta x_{1}\right\rangle$ も同様な手続きで悠密に計算で きる。

$$
\left\langle(\Delta N)^{2}\right\rangle=\left\langle\left(\Delta N_{1}\right)^{2}\right\rangle+\left\langle\left(\Delta N_{2}\right)^{2}\right\rangle+2\left\langle\Delta N_{1} \Delta N_{2}\right\rangle
$$

であるから(12)を用いて

$$
\begin{aligned}
\left.\langle\Delta N)^{2}\right\rangle & =k_{\mathrm{B}} T\left[A_{22}+A_{11}-A_{12}-A_{21}\right] /|A| \\
& =N\left[n k_{\mathrm{B}} T \kappa_{T}+N^{2}\left\langle\left(\Delta x_{1}\right)^{2}\right\rangle\left\{\left(v_{1}-v_{2}\right) / v\right\}^{2}\right]
\end{aligned}
$$

を得る、ただし $n=N / V=1 / v$ である．同じ手続きで次 式が求められる。

$$
\begin{aligned}
\left\langle\Delta N \Delta x_{1}\right. & \left.>=x_{2}<\left(\Delta N_{1}\right)^{2}>-x_{1}<\left(\Delta N_{2}\right)^{2}\right\rangle \\
& +\left(x_{2}-x_{1}\right)<\Delta N_{1} \Delta N_{2}>=k_{\mathrm{B}} T\left[x_{2} A_{22}-x_{1} A_{11}\right. \\
& \left.+x_{2} A_{12}-x_{1} A_{21}\right] /|A|=k_{\mathrm{B}} T\left[\left\{\left(v_{2}-v_{1}\right) / v\right\} x_{2} /\right. \\
& \left.\left(\partial \mu_{1} / \partial x_{1}\right) T, p\right]
\end{aligned}
$$

これらの結果は次節で述べるゆらぎの理論にもとづいて 導かれた Bhatia, Thornton ${ }^{(1)} の$ 表現と勿論一致してい る.

\section{3. 溶液の熱力学的安定性とゆらぎの関係}

平衡状態にある孤立系に生ずるゆらぎは常にそのエン トロピーSの減少を伴うことが要請される. 若し増大 することがあれば，出発した状態が不安定であったこと になり，熱力学の第 2 法則に従って, もっと安定な状態 に移る筈だからである. 従って熱力学的平衡の安定条件

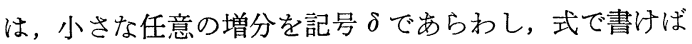
この場合

$$
\delta S \leqslant 0
$$

となる(11).ただし; この系のエネルギー, 体積, 粒子 数は一定に保たれていると考えている.

エントロピー $S$ をその平衡值 $S_{e}$ のまわりで Taylor 展開すると

$$
S=S_{e}+(\delta S)_{e}+\frac{1}{2}\left(\delta^{2} S\right)_{e}+\cdots
$$

のように書ける。前述の孤立系の条件から 1 次の展開項 は常に零である. 従って安定条件 (20) は微小の変化に対 して

$$
(\delta S)_{e}=0 \quad \text { (平 衡) }
$$


$\left(\delta^{2} S\right)_{e}<0 \quad$ (安定性)

$\left(22^{\prime}\right)$

と書ける。これはエントロピーSが極大となることを 示している.

ここで孤立系を $a, b, c \cdots$ のよな部分系に分け，それ ぞれの領域での熱力学的変数を上添字 $(a),(b),(c) \cdots て ゙$ あらわし, 温度, 体積, 粒子数の変化に対応してェント ロピーがどのように変るかを調べよう，少し長い計算の 後(12), $\left(\delta^{2} S\right)_{e}$ として

$$
\begin{aligned}
\left(\delta^{2} S\right)_{e}= & \sum_{a} \frac{1}{T}\left[-\frac{C_{v}}{T}\left(\delta T^{(a)}\right)^{2}-\frac{1}{V \kappa_{T}}\left(\partial V^{(a)}\right)^{2}\right. \\
& -2 \sum_{\alpha}\left(\frac{\partial \mu_{\alpha}}{\partial V}\right)_{T,\{N\}} \delta N_{\alpha}^{(a)} \delta V^{(a)} \\
& -\sum_{\alpha, \beta}\left(\frac{\partial \mu_{\alpha}}{\partial N_{\beta}}\right)_{T, V,\left\{N_{\beta^{\prime} \neq \beta}\right\}} \delta N_{\alpha}^{(a)} \delta N_{\beta}^{(a)}
\end{aligned}
$$

を得る，ただし $C_{v}$ は定容熱容量である，特に温度，体 積が一定に保たれた場合この式は

$$
\left(\delta^{2} S\right)_{e}=-\sum_{\alpha, \beta} A_{\alpha \beta} \delta N_{\alpha} \delta N_{\beta} / T
$$

と書ける。 $A_{\alpha \beta}$ は式(13)で定義されて捈り， $\delta N_{\alpha} \delta N_{\beta}$ は 各部分の $\delta N_{\alpha}^{(a)} \delta N_{\beta}^{(a)}$ の総和をあらわしている.

ところで Einstein のゆらぎの理論では，ゆらぎを生 ずる確率が

$$
P_{\mathrm{E}}=\text { const } \cdot \exp \left(\Delta S / k_{\mathrm{B}}\right)
$$

であるとする(8)-(12)， $\Delta S$ はゆらぎに伴うェントロピー 変化である。この $\Delta S$ が(21)で示される微小な変化 $S-S_{e}$ で記述できるときは，前述のように $(\delta S)_{e}=0$ で あるから，(24)より $\left(\delta\right.$ をで置き換えて) $P_{\mathrm{E}}$ は

$$
P_{\mathrm{E}}=\text { const. } \exp \left[-\sum_{\alpha, \beta} A_{\alpha \beta} \Delta N_{\alpha} \Delta N_{\beta} /\left(2 k_{\mathrm{B}} T\right)\right]
$$

と書け，Gauss 分布の形をとる。いろいろの物理量に対 してこの分布による平均値を計算することは容易で ある ${ }^{(8)-(10)}$. 事実, Bhatia ら ${ }^{(1)}$ はこの関数を使って $\left\langle\left(\Delta x_{1}\right)^{2}\right\rangle,\left\langle(\Delta N)^{2}\right\rangle,\left\langle\Delta N \Delta x_{1}\right\rangle$ を計算し, $(2)$ ， (18)，(19)を得たわけである。な拈，彼らの論文では

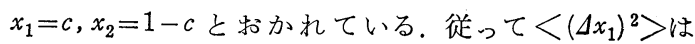
$\left\langle(\Delta c)^{2}\right\rangle$ と書かれている.

また Hill(9), Landau-Lifshitz ${ }^{(10)}$ の教科書では溶質と 溶媒の粒子数比，たとえば $N_{1} / N_{2}$ をと拈き溶媒粒子

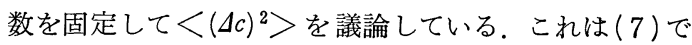
いうと $\Delta N_{1}$ の影響だけを考慮することを意味する。こ の条件は希薄溶液では有効であるが，Bhatia-Thornton の式にくらべると一般性に欠けている.

次に温度, 圧力一定のもとでのエントロピー変化の式 を求めてみょう。式(24)を得た過程に類似した計算を行 うことによって

$$
\Delta S=-\sum_{\alpha, \beta}\left(\partial \mu_{\alpha} / \partial N_{\beta}\right)_{T, p,\left\{N_{\beta^{\prime}} \neq \beta\right\}} \Delta N_{\alpha} \Delta N_{\beta} / T
$$

を得る。この式と $(20)$ あるいは $\left(22^{\prime}\right)$ から 2 成分溶液が ( 2 相分離を生ずることなく) 熱力学的に安定に存在する 条件は
と置いて

$$
\mu_{\alpha \beta \beta} \equiv\left(\partial \mu_{\alpha} / \partial N_{\beta}\right) T, p,\left\{N_{\beta^{\prime} \neq \beta}\right\}
$$

$$
\mu_{11}\left(\Delta N_{1}\right)^{2}+\mu_{22}\left(\Delta N_{2}\right)^{2}+2 \mu_{12} \Delta N_{1} \Delta N_{2}>0
$$

と書ける。この不等式が常に成立するためには最終的に

$$
\mu_{11}>0 \text { ，または } \mu_{22}>0
$$

であればよい(13)。すなわち

$$
\left(\partial \mu_{\alpha} / \partial x_{\alpha}\right)_{T, p}>0 \text {, または }\left(\partial \mu_{\alpha} / \partial x_{\beta}\right)_{T, p}<0
$$

この不等式は拡散に関する安定条件と呼ばれてい る(11) (13)

Darken ${ }^{(14)}$ は $\left(\partial^{2} G / \partial x_{\alpha}^{2}\right)_{T, p}$ を安定度 (stability), 過剩 自由エネルギー $G^{\mathrm{EX}}$ の同様な 2 次微分係数

$\left(\frac{\partial^{2} G^{\mathrm{EX}}}{\partial x_{\alpha}^{2}}\right)_{T, p}=\frac{1}{x_{\beta}}\left(\frac{\partial \mu_{\alpha}^{E X}}{\partial x_{\alpha}}\right)_{T, p}=-2 N k_{\mathrm{B}} T\left\{\frac{\partial \ln f_{\alpha}}{\partial\left(x_{\beta}^{2}\right)}\right\}_{T, p}$

を過剒安定度 (excess stability) と名付けた。上添字 $E X$ は過剩量を示す。これらの量と濃度ゆらぎ, 安定条件と の関係は (2)，(30)により明らかである。

まえがきで述べたように相互拡散係数 $D_{12}$ は式 (4)の ように書ける， $D_{12}^{\mathrm{Id}}$ は常に正であることに注意すると， 式(2)，(3)を参照して(30)の不等式が成立している場 合 (換言すれば $\left\langle\left(\Delta x_{1}\right)^{2}>\right.$ が正のとき)にのみ $D_{12}$ が正 となることがわかる，この不等式が成立して始めて物質 は濃度の高い方から低い方に流れて行くことができる。 前述のようにこの式 (30) を拡散安定条件と呼ぶことは自 然である。

\section{4. 濃度ゆらぎと静的, 動的構造因子}

これまで述べてきたゆらぎは巨視的観測によって見出 だされるゆらぎであった。これを進めて微視的なゆらぎ を論ずることは，構成粒子の空間的，さらには時間的分 布すなわち静的あるいは動的構造を知ろうとすることに 他ならない, 液体の静的構造の研究(15)-(17) はX線, 中性 子線回折実験によって行われており，これらの実験で得 られる回折強度は散乱角 $\theta$ または散乱ベクトル

$$
q=|\boldsymbol{q}|=(4 \pi / \lambda) \sin (\theta / 2)
$$

の関数としてあらわされる、入はX線または中性子線の 波長である。この回折強度のらち構造に関連した寄与が 構造因子と呼ばれる量であり， $\alpha-\beta 2$ 成分系の場合頂度 実際の空間での 2 体相関関数 $q_{\alpha \beta}^{(2)}(\boldsymbol{R})$ を Fourier 変換し た量

$$
S_{\alpha \beta}(\boldsymbol{q})=\delta_{\alpha, \beta}+\frac{N\left(x_{\alpha} x_{\beta}\right)^{1 / 2}}{V} \int\left[q_{\alpha \beta}^{(2)}(\boldsymbol{R})-1\right] \mathrm{e} \mathbf{i} \cdot \cdot \boldsymbol{R} \mathrm{d}^{3} R
$$

になっている，2成分系の場合には $\alpha-\alpha, \beta-\beta$,さらに $\alpha-\beta$ の三種の部分構造因子が定義される， $\mathrm{i}^{2}=-1$ であ り， $\delta_{\alpha \beta}$ は $\alpha=\beta$ のとき $1, \alpha \neq \beta$ のとき零となる。構造 因子では位置ベクトル $\boldsymbol{R}$ の代りに, 長さの逆数の次元 を持つ $\boldsymbol{q}$ を用いてその挙動が記述される。また動的構 
造の研究でも時間 $t$ に依存するゆらぎは, 時間の逆数の 次元を持った角振動数 $\omega$ を使って論ぜられることが多 W.

成分 $\alpha$ の粒子数密度 $n_{\alpha}$ は $N_{\alpha} / V$ で定義され, 平均数 密度 $\left\langle n_{\boldsymbol{\alpha}}\right\rangle$ は $\left\langle N_{\boldsymbol{\alpha}} / V\right\rangle$ で与えられる. 従って場所 $\boldsymbol{R}$, 時刻 $t$ における (数) 密度の偏差は

$$
\delta n_{\boldsymbol{\alpha}}(\boldsymbol{R}, t)=n_{\boldsymbol{\alpha}}(\boldsymbol{R}, t)-\left\langle n_{\boldsymbol{\alpha}}\right\rangle
$$

と書ける。これをFourier 展開の形であらわすと

$$
\begin{gathered}
\delta n_{\boldsymbol{\alpha}}(\boldsymbol{R}, t)=(1 / V) \sum_{\boldsymbol{q}} N_{\boldsymbol{\alpha}}(\boldsymbol{q}, t) \exp (-\mathrm{i} \boldsymbol{q} \cdot \boldsymbol{R}) \\
N_{\boldsymbol{\alpha}}(\boldsymbol{q}, t)=\int \exp (\mathrm{i} \boldsymbol{q} \cdot \boldsymbol{R}) \delta n_{\boldsymbol{\alpha}}(\boldsymbol{R}, t) \mathrm{d}^{3} R
\end{gathered}
$$

となる. 式(8)になららと, 局所的な濃度の偏差を示す $\delta x_{1}(\boldsymbol{R}, t)$ は

$$
\delta x_{1}(\boldsymbol{R}, t)=(V / N)\left[x_{2} \delta n_{1}(\boldsymbol{R}, t)-x_{1} \delta n_{2}(\boldsymbol{R}, t)\right]
$$

の形に書け，その Fourier 変換は

$$
\begin{aligned}
x_{1}(\boldsymbol{q}, t) & =(1 / V) \int \delta x_{1}(\boldsymbol{R}, t) \exp (\mathrm{i} \boldsymbol{q} \cdot \boldsymbol{R}) \mathrm{d}^{3} R \\
& =N^{-1}\left[x_{2} N_{1}(\boldsymbol{q}, t)-x_{1} N_{2}(\boldsymbol{q}, t)\right]
\end{aligned}
$$

となる

Bhatra, Thornton ${ }^{(1)}$ はこの $x_{1}(\boldsymbol{q}, t)$ を用いて濃度ゆらぎ の動的構造因子 $S_{c c}(q, \omega)$ を次のように定義した。

$$
S_{c c}(q, \omega)=\frac{N}{2 \pi} \int \mathrm{e}^{-\mathrm{i} \omega t}\left\langle x_{1}(-\boldsymbol{q}, 0) x_{1}(\boldsymbol{q}, t)\right\rangle \mathrm{d} t .
$$

この式の $\left\langle x_{1}(-\boldsymbol{q}, 0) x_{1}(\boldsymbol{q}, t)\right\rangle$ は変数 $x_{1}(\boldsymbol{q}, t)$ の時間

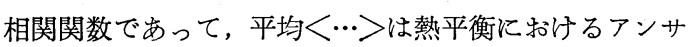
ンブル (ensemhle) 平均, あるいは $t=0$ 以前についての 長時間平均をあらわしている。

時間 $t$, あるいは角振動数 $\omega$ に依存しない濃度ゆらぎ の相関をあらわす関数は $S_{c c}(q, \omega)$ をすべての $\omega$ につい て積分することによって得られる. Dirac のデルタ関数 に対する数学的な関係

$$
\int \mathrm{e}^{-\mathrm{i} \omega t} \mathrm{~d} \omega=2 \pi \delta(t)
$$

を使うといわゆる静的構造因子として

$$
S_{c c}(q)=\int S_{c c}(q, \omega) \mathrm{d} \omega=N\left\langle x_{1}(-\boldsymbol{q}) x_{1}(\boldsymbol{q})\right\rangle
$$

を得る。なお，前節までに述べたゆらぎは巨視的なるの であり， $\boldsymbol{q}$ としては零に近ずいた極限，すなわち長波長 極限で観測されるすのとみることができる.この極限で は, $x_{1}(\boldsymbol{q}, t)$ は式 $(8)$ の $\Delta x_{1}$ に近ずくから

$$
S_{c c}(0)=N\left\langle\left(\Delta x_{1}\right)^{2}\right\rangle=\frac{x_{1} x_{2}}{1+\left(\partial \ln f_{1} / \partial \ln x_{1}\right) T, p}
$$

が得られ, 熱力学的表現 (2)に帰着する. $f_{1}$ の濃度変化 が精密, 正確に実験的に分っている限り, この式を用い $\tau S_{c c}(0)$ を求めることは容易である(18).

$S_{c c}(q, \omega)$ は $q \rightarrow 0 \omega=0$ の条件下で Lorentz 型すなわち

$$
S_{c c}(q, \omega)=S_{c c}(0) \frac{q^{2} D_{12}}{\pi\left\{\omega^{2}+\left(q^{2} D_{12}\right)^{2}\right\}}
$$

の形に書け(19)(20), 熱力学的要素 $S_{c c}(0)=N\left\langle\left(\Delta x_{1}\right)^{2}\right\rangle$
と輸送現象にかかわる要素 $D_{12}$ を用いてあらわされるこ とに注意しよう。

(31) - (39)の各式から $S_{c c}(q, \omega)$ および $S_{c c}(q)$ は部分構 造因子 $S_{\alpha \beta}(q, \omega), S_{\alpha \beta}(q)$ を使ってあらわすこともでき る。たとえば

$$
S_{c c}(q)=x_{1} x_{2}\left[x_{2} S_{11}(q)+x_{1} S_{22}(q)-2\left(x_{1} x_{2}\right)^{1 / 2} S_{12}(q)\right]
$$

しかし，実際の液体合金系ではこれら部分構造因子の実 験的知識は精度的に必ずしも十分とはいえない。今後の 研究課題である。ただし， $\mathrm{Li}_{4} \mathrm{~Pb}$ 合金については例外的 に $S_{c c}(q)$ および $S_{c c}(q, \omega)$ の直接測定の結果が報告されて いる ${ }^{(21)-(23)}$. Li- $\mathrm{Pb}$ 合金のこの組成では, 各原子核の中 性子散乱のパラメーター (干渉性散乱長) の平均值が零と なり，観測される中性子散乱強度が直接 $S_{c c}(q), S_{c c}(q, \omega)$ の知識をあたえるという幸運に恵まれているためであ る。また式(47)によって定義される $S_{c c}(0)$ すなわち $N<\left(\Delta x_{1}\right)^{2}>$ の熱力学的測定値 ${ }^{(24)}$ は $\mathrm{Li}_{4} \mathrm{~Pb}$ 組成で著し く小さく，ゆらぎが極端に減少していることを示してい る.このほか多くの物性值の異常が見出だされており， この系は化合物形成傾向の強い典型的な合金系である. しかし中性子非弾性 散乱実験による $S_{c c}(q, \omega)$ の結果 ${ }^{(23)}$ はピコ秒をこえる長寿命の化合物の存在を支持していな い.

\section{5. 液体合金のモデルと濃度ゆらぎ}

溶液の各成分の化学ポテンシャル $\mu_{\alpha}$ または活量係数 $f_{a}$ の濃度変化を示す理論式があたえられれば, 熱力学 的意味での濃度ゆらぎは式 (2)または (42)を用いてただ ちに計算できる。最も簡単な理想溶液では活量係数は 1 に等しいから濃度ゆらぎは

$$
\left.S_{c c}(0)=N<\left(\Delta x_{1}\right)^{2}\right\rangle=x_{1} x_{2}
$$

となる。すた正則溶液 (regular solution) では $\ln f_{1}=$ $w\left(1-x_{1}\right)^{2} / k_{\mathrm{B}} T$ (ただし， $w$ は定数) が成り立っているか ら濃度ゆらぎとして

$$
\left.S_{c c}(0)=N<\left(\Delta x_{1}\right)^{2}\right\rangle=\frac{x_{1} x_{2}}{1-2 x_{1} x_{2} w /\left(k_{\mathrm{B}} T\right)}
$$

を得る。この式(46)はいわゆる conformal solution の理 論 ${ }^{(25)}$ とっても得ることができる(この理論は相応状態 の原理を溶液系に拡張したもので, 適当な参照液体の状 態量を使って溶液の熱力学的諸量の相互関係が記述され る.この立場から 2. で述べたゆらぎの統計熱力学の関 係を用いて金属溶液の $w$ その他の量の相互関係を論ず ることもできる(26). しかし，分子性液体の場合と異な り，金属性液体では伝導電子の存在の故に相応状態の概 念が有効とはいえず(27)，原理的には疑問が残る。

このほか，金属溶液の統計熱力学的研究としては大別 して固体的アプローチ(準結晶模型およびその改良型)， 流体的アプローチ(分布関数法)の 2 つがある．前者では 
液体が適当な配位数を持った結晶あるいは短範囲秩序の 集合体として扱われ，その構造模型に基づいて粒子間の 相互作用エネルギーが評価され，熱力学的な量が計算さ れる。このやり方は現実の液体の構造を必ずしも忠実に 反映するモデルといえない。しかし，溶液論においては 溶液と純液体それぞれに打ける量の差が問題となるので (ある意味ではこの差を考光る際, 液体構造固有の問題 が相殺するともい克る)，定性的な傾向を知るには有効

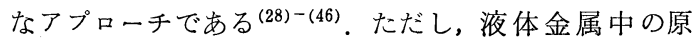
子間ポテンシャルの距離(あるいは体積) 依存性は通常の 分子性液体の場合と大きく異なることに注意をはらわな ければならない(30) (32) (35) (47) (48).

一方, 分布関数法 ${ }^{(48)}$ 基づく理論の代表としてはいわ ゆる熱力学的摂動論がある ${ }^{(49)-(54)}$. 参照液体として剛体 球系を選び，原子間相互作用は擬ポテンシャル理論を用 いて摂動論的に計算されたるのを用いる。 Helmholtz 自 由エネルギーは剛体球系の自由エネルギーと(その 2 体 配置分布関数を用いて書き下された)原子間相互作用エ ネルギーの和として表わされる。この方法による熱力学 的計算はかなりの成功を収めている。

しかし，Li-Pb のように，異種原子間に強い化学的相 互作用が働いていると考觉る系では，単純な剛体球系を 参照液体とすることは適当ではない，そこで溶融塩，あ るいは、電解質溶液の理論計算飞拈ける MSA (mean spherical approximation), すなわち剛体球 (Hard Sphere) ポテンシャルに湯川 (Yukawa) 型 (指数関数型遮 閉を伴った)静電ポテンシャルを加えたいわゆる HSY 型 相互作用の粒子系を構造モデルとすることが試みられて いる ${ }^{(55)(56)} \cdot \mathrm{Li}_{4} \mathrm{~Pb}$ 系の実測の $S_{c c}(q)$ をこのモデルを用い て再現するためには， $\mathrm{Li}, \mathrm{Pb}$ 原子の見掛けの電荷がそれ ぞれ約 $0.5,-2$ の程度であればよく, 同様の $S_{c c}(q)$ の 計算結果は剛体球ポテンシャルを指数関数型斥力ポテン シャルに置換した場合でも見出だされている(55)。この

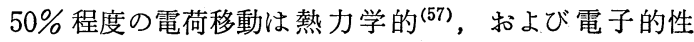
質 ${ }^{(58)}$ の計算でも予想されていた程度の量である。しか し,このHSY 型ポテンシャルの溶液を参照系とする熱力 学的計算は, まだ定量的満足すべき段階にはない、 ${ }^{(56)}$. 前述のように,この合金の電気抵抗值は非常に大き く, 伝導電子の平均自由行路は平均原子間距離の程度ま で低下して括り，この電子系の挙動が必ずしも通常の ほぼ自由な電子ガスとして扱い得ないことによるもので あろら。

化合物形成傾向の強い液体合金に対してょく用いられ るアプローチにいわゆる会合モデル(30)(59)-(72)がある. これはいわゆる Raoult の法則より著しく負に偏倚する 溶液系に対して提案されてきた(ある意味では古典的な) 模型であるが(30)，濃度ゆらぎを意識した適用は Bhatia，
Hargrove ${ }^{(60)}$ が最初である、A-B 2 成分の合金溶液中に， 適当な組成の化合物 $\mathrm{A}_{\mu} \mathrm{B}_{\nu}(\mu, \nu$ は小さい整数)の存在を 仮定し, $\mathrm{A}, \mathrm{B}, \mathrm{A}_{\mu} \mathrm{B}_{\nu}$ の 3 種の成分から出来ているとして 自由エネルギーの式を書き(ここで必要ならば活量係数 飞対応する相互作用を考慮する)，その化合物の濃度は この自由エネルギーが極值をとるといら条件抢よび自由 エネルギーそのものの測定値から決められる。このよう として計算される $S_{c c}(0)$ の值は Tl-Te, $\mathrm{Mg}-\mathrm{Bi}, \mathrm{Ag}-\mathrm{Al}$, $\mathrm{Cu}-\mathrm{Sn}$ 等の場合実験結果とよく一致している。このア プローチはさらに各種の系について展開され(60)-(72), かなり実験結果を説明しているといえる。しかし，この モデルの難点は, この種の化合物の微視的構造, 寿命に 対する定量的解明と実証がまだ十分ではないことであ る. 前述したように $\mathrm{Li}_{4} \mathrm{~Pb}$ 系汶対する中性子非弾性散乱 の結果 ${ }^{(23)}$ では, 今の所化合物形成を示すような秩序度 の寿命は高々 $10^{-12}$ 秒程度であり, 安定な化学種の寿命 としては短か過ぎるようである。

ここで, 構造因子(微視的なスケールでのゆらぎ) の温 度あるいは圧力変化は, 原子配置の高次相関と密接阔関 連していることを注意して祘こう ${ }^{(73)}$ 。とれは水銀合金 等に見出だされる特異な挙動の原因と考兄られるもので ある。

\section{6. 非線型非平衡過程における濃度ゆらぎ}

平衡状態から発生するゆらぎは時間の経過と共に減 少，消隇し，もとに戻ってしまう。これまで述べて来た ゆらぎはこの種のものであった，その大きさは小さく， 熱力学, 平衡扣よび線型非平衡統計力学によって少なく とも原理的には之の本質が理解されているといってよい であろう. 残る問題はいかに現実の物質系の平衡状態若 しくはその近傍での挙動を定量的に説明，あるいは予言 し得るかといらことである.今後もこのような研究は活 発に進められていくことであろう。

しかし，平衡から著しく離れた状態で生ずるゆらぎの 性質は事情が全く異なってくる。そこではゆらぎが時間 と共に減少せずに反対に成長して行く場合があり（終局 的には，そのゆらぎが消滅してしまうにせよ)，非平衡 状態特有の構造があらわれる可能性がある。いわゆる散 逸構造 (dissipative structure) の出現である。この問題 は線型非平衡過程の熱力学および統計力学の枠をこえて いる. 現在の段階ではそれを統一的, 効果的汇記述する 基礎原理が確立されているとはいい難いが，ここでこの ような条件下での金属溶液の濃度ゆらぎの例について少 乙触れて拉くことにする。1 1 つ融体精錬反応浴のガス 擋拌，もら 1 つは金属の急速凝固である.

\section{（1）反応浴のガス擋挥}

現代の精錬反応被置に打いては，融体浴中にガスを吹 
き込み反応の促進を図ることが多い。このとき(慣性力 と粘性力の比できまる) Reynolds 数が増加してある限界 を越えれば融体は乱流状態となり,空間的,時間的に極め て不規則な流れを示す ${ }^{(74)}$. その中での物質移動速度は 勿論前節で述べた㧪散係数で記述することができず， “乱流輸送係数”とでもいらべき量が経験的に定義され ることになる ${ }^{(75)}$. 実際問題としては，反応の促進のた めに炉内融体の濃度を速やかに均一にする必要があり， 種々の観点から均一混合に要する時間と擋拌エネルギー 密度との関係などが，水槽を用いたモデル実験によって 検討されている(75)(76)

更にくわしく考察するためには，流動の時間的，空間 的変化と局所的なエネルギー散逸の関係を知ることが必 要である，乱流に対する統計理論の立場からは，位置 $\boldsymbol{R}$, 時刻 $t$ での速度 $\boldsymbol{u}(\boldsymbol{R}, t)$ またはその Fourier 変換 $\boldsymbol{v}(\boldsymbol{q}, \omega)$ の分布を知り，その分布関数を用いて局所的な エネルギー密度を求める検討が進められる．勿論この分 布関数は平衡状態または線型統計力学で微視的に定義さ れるものとは異なり，乱流発生条件下での巨視的な速度 のアンサンブルを扱うものである。実験的には先ず液中 に流速計を設置して速度をサンプリングし，それから速 度分布，あるいはその変動速度 (平均速度からのずれ)の 自乗のアンサンブル平均，すなわち空間的あるいは時間 的変化のスペクトル密度 $P(\boldsymbol{q}), P(\omega)$ が求められる.渡辺 $ら^{(77)}$ は水モデル実験によってこれらのスペクトル密度 を決定し，エネルギー散逸を論じている，その結果， $P(\omega)$ について周波数 $1 \mathrm{~Hz}$ 附近に鋭いピーク構造を見出 だし，さきに加藤ら ${ }^{(76)}$ が水モデル実験から見出だした 底吹き転炉内の鋼浴振動と対応するものとしている。濃 度のゆらぎもそれに追随している筈である，非平衡状態 特有の振動現象の 1 つであるといえよう.

融体精錬反応では，このような単なる流動，撹拌の泀 かに化学反応が附随し，しかもそれからは著しく平衡か ら離れた状態から出発することが多い。ミクロ的に見た それらの過程は非常に興味深い問題である。

\section{（2）金属の急速凝固}

凝固が迅速に進行する場合，固・液界面で熱平衡もし くはそれに近い状態が保たれず，熱力学的に安定とはい えない構造の固相の出現を見ることがある，過冷却の程 度, 冷却速度などの差異によって種々の準安定固相, アモ ルファス固体 ${ }^{(78)}$ ，あるいは準 結晶 ${ }^{(79)}$ などを得ることが 可能である。この急速冷却は新材料開発の観点からも大 変注目されている問題である．新宮, 石原 ${ }^{(80)(81)}$ が強調 しているように，この急冷凝固過程の支配因子は過冷却 液体と種々の固相の間の自由エネルギー差であり，それ は古典核生成理論の立場からも容易に理解される所であ る.このことを溶液のゆらぎの観点からいらならば，過
冷却液相中に生じるゆらぎの中に固相の embryo も含ま れ, それらは生成, 消隇を繰返し, ある臨界的な大きさ に生成した embryo のみが固相成長の核として作用する ことが許される.この過程の速度論的解明には, 前記の 自由エネルギー差に加えて，いくつかの非平衡論的要素 に対する考慮が必要である。しかし，過冷溶液でのゆら ぎの時間的, 空間的変化についての具体的な研究はまだ 始まったばかりである ${ }^{(82)}$. 一方, 固相に拉ける非平衡 1 次相転移の研究は最近急速に発展している。そこでは濃 度ゆらぎが Fourier 変換された量として定義され，その 値は実験的にも中性子の小角散乱の測定によって求めら れつつある(83). そしてそれがいわゆる動的スケーリン グ則 ${ }^{(84)}$ に従うことも徐々に明らかになってきている. 将来実験技術の進歩によって過冷液体合金の相転移につ いても，この種の知識が得られることが望まれる.

一方, アモルファス固体生成の問題では, 事情が少し 異なる。安定相, 準安定相はともに自由エネルギーが (その高低は別として)極小を示している状態である。そ の結果, エンタルピー, エントロピー等は何れる転移点 で不連続的な変化を示す。とこがアモルファス固体で は熱力学的意味での安定性が保証されておらず, 過冷液 体からのガラス転移過程でのエンタルピー変化にも不連 続性は見出だされない. 比熱, 熱膨張係数等のピークを 伴う “2 次相転移類似の挙動”が観測されている。その 原因は熱力学的なものではなく, 構造変化の動的過程に あるものと考元られ, 種々の理論的検討 ${ }^{(85)-(88)}$ が試みら れている，その本質は急激な冷却によって構造が温度变 化に追随出来ず，アモルファス状態では所定温度の(厳 密な意味での)過冷液体の場合よりも過剰なエントロピ 一，体積などがゆらぎとして保存されることにあるもの と考えられる(89)-(91)。換言すれば，エネルギー散逸に 関係した固有の構造緩和速度と外的条件によってきまる 冷却速度の大小関係が，ガラス転移の出現に重要な役割 を果たしているといえる。このことは乱流発生の条件が Reynolds 数の大きさによって支配されている事情とよ く似ている。

非平衡を引き起す力とその効果を散逸させる力の関係 を明確化することが, 非線型非平衡現象を理解するため の基本的出発点であろう。さらに考察を進めて行くため には,新しいアプローチとして Glansdorff, Prigogine(11) の時間発展規準の理論，あるいは Haken ${ }^{(92)}$ が提唱する synergetics 的な解析の考方方なども参考になるであろ

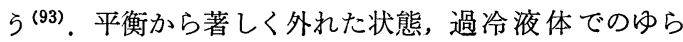
ぎに関する本格的な解明はこれからのことである。

\section{7. ま め}

溶液中に生じている濃度ゆらぎは，その溶液の熱力学 
的安定度を定量的に示す量であると共に，相互拡散係数 の重要な因子である。そして微視的なスケールでの濃度 ゆらぎの知識はその時間相関関数あるいは静的, 動的構 造因子の情報の中に包含される。これらの理論的基礎 は，平衡ならびに線型非平衡統計力学の立場から理解 されるものであり，ここでは金属溶液論の立場からその 発展の簡単な展望を試みた。詳細は引用文献を参照され たい.

さらに平衡から著しく離れた状態での濃度ゆらぎにつ いてもその特徵を反応浴のガス擋拌, 急速凝固の 2 つの 場合を例として手短かに述べた。しかし，その基礎原理 の研究はまだ未開拓の分野に属している.胎動の段階に あるといってよいであろう。

何れにせよ, 溶液の安定度は濃度ゆらぎに密接に関係 し, その動的過程もまた濃度ゆらぎ深く関与してい る。これら濃度ゆらぎに関連する研究は液相, 固相を問 わず，金属の研究では極めて重要な課題である，多方面 からの新しい研究が強力に展開されて行くことが期待さ れる。な挔, 引用文献の作成については伊丹俊夫，河村 純一両氏の援助を受けた，厚く謝意を表する。

\section{文献}

(1) A.B.Bhatia and D.E.Thornton: Phys. Rev. B, 2(1970), 3004.

( 2 ) M.Shjmoji and T.Itami : Atomic Transport in Liquid Metals, Trans Tech Publications, Aedermannsdorf, Switzerland, (1986), 8.

( 3 ) L.S.Darken and R.W.Gurry: Physical Chemistry of Metals, McGraw-Hill, New York (1953), 463.

(4) F.D.Richardson : Physical Chemistry of Melts in Metallurgy, Academic Press, London, (1974), 18.

( 5 ) M.Shimoji : Liquid Metals, Academic Press, London, (1977), 229.

( 6 ) K.Niwa, M.Shimoji, S.Kado, Y.Watanabe and T. Yokokawa : Trans. AIME, 209(1957), 96 ; 丹羽貴知蔵, 下地光雄, 門智, 渡辺芳彦: 日本金属学会誌, 18 (1954), 271，274，276; 丹羽貴知蔵, 下地光雄, 阴 智, 渡辺芳彦，横川敏雄 : 日本金属学会誌, 19(1955), 294, 296, 299.

( 7 ) 文献 (2), p.176.

( 8 ) R.C.Tolman: The Principles of Statistical Mechanics, Oxford Univ. Press, London, (1938), 641.

(9) T.L.Hill : Statistical Mechanics, McGraw-Hill, New York, (1956), 113.

(10) L.D.Landau and E.M.Lifshitz : Statical Physics, Pergamon,London, (1959), 344.

(11) P.Glansdorff and I.Prigogine : Thermodynamic Theory of Structure, Stability and Fluctuations, Wiley, London, (1971), 44.

(12) 例えば, L.E.Reichl : A Modern Course in Statistical Physics, Univ. Texas Press, Austin (1980) ; 邦訳, 現代 統計物理(鈴木增雄監訳), 丸善, 上巻, 42 .

(13) I.Prigogine and R.Defay: Chemical Thermodynamics (trans.D.H.Everett), Longmans Green, London,(1954), 224.

(14) L.S.Darken : Trans. AIME, 239(1967), 80.

(15) N.H.March and M.P.Tosi : Atomic Dynamics in Liquids, McMillan, London, (1976), 1.

(16) Y.Waseda: The Structure of Non-Crystalline Materials (Liquids and Amorphous Solids), McGraw-Hill, New York, (1980), 1.

(17) 文献(5), p.57.
(18) K.Ichikawa and J.C.Thompson: J. Chem. Phys., 59 (1973), 1680 : J.C.Thompson, K.Iciikawa and S.M Granstaff, Jr : Phys. Chem. Liquids, 5(1976), 167 ; A B.Bhatia : Liquid Metals, Conf. Ser. No.30, Inst. Phys., Bristol, (1977), 21. M.Shimoji : J. de Phys., 41(1980), C8-547.

(19) A.B.Bhatia, D.E.Thornton and N.H.March: Phys. Chem. Liquids, 4(1974), 93.

(20) 文献(2), p.133; 文献(14), p.302.

(21) H.Ruppersberg and H.Egger : J.Chem. Phys., 63(1975), 4095 ; H.Ruppersberg and H.Reiter : J.Phys. F, 12 (1982), 1311.

(22) M.Soltwisch, D.Quitmann, H.Ruppersberg and J.-B. Suck : J. Phys. (Paris) 41(1980) C8-167; Phys. Lett., $86 \mathrm{~A}(1981), 241$; Ionic Liquids and Polyelectrolytes, Ed. by K.H.Bennemann et al., Springer, Berlin, (1982), 136.

(23) M.Soltwisch, D.Quitmann, H.Ruppersberg and J.-B. Suck : Phys. Rev. B, 28(1983), 5583.

(24) M.L.Saboungi, J.Marr and M.Blander : J. Chem. Phys., 68(1978), 1375.

(25) H.C.Longuet-Higgins : Proc. Roy. Soc., A205(1951), 247.

(26) A.B.Bhatia, W.H.Hargrove and N.H.March : J. Phys. C, 6(1973), 621 .

(27) 文献(5), p.27.

（28）竹内 栄: 日本金属学会誌, B-14(1950), 1 .

(29) 斎藤恒三: 日本金属学会誌, B-14(1950), 26.

(30) J.H.Hildebrand and R.L.Scott: Solubility of NonElectrolytes, Reinhold, New York, (1950).

(31) J.Lumsden: Thermodynamics of Alloys, Inst. Metals, London, (1952).

(32) M.Shimoji and K.Niwa : Acta Met., 5(1957), 496.

(33) B.W.Mott : Phil. Mag., 2(1957), 259.

(34) 堀川映二 : 鉄と鋼, 44(1958), 533.

(35) 古川和男: 日本金属学会誌, A-23(1959), 322; The Properties of Liquid Metals Ed. by S.Takeuchi, Taylor \& Francis, London, (1973), 461.

(36) C.B.Alcock and F.D.Richardson : Acta Met., 6(1958), 385 ; ibid., 8(1960), 882.

(37) H.Wada and T.Saito: Trans. JIM, 2(1962), 15.

(38) C.H.P.Lupis and J.F.Elliott : Acta Met., 14(1966), 1019 ; ibid., 15(1967), 265.

(39) J.Chipman : Trans. AIME, 239(1967), 1332.

(40) K.T.Jacob and C.B.Alcock : Acta Met., 20(1972), 221.

(41) C.H.P.Lupis : Liquid Metals (ed. S. Z. Beer), Marcel Dekker, New York, (1972), 1.

(42) C.Wagner : Acta Met., 21(1973), 1297.

(43) S.Tamaki : The Properties of Liquid Metals, Ed. by S. Takeuchi, Taylor \& Francis, London, (1973), 455.

(44) 文献(4), p.147.

(45) M.Blander, M.-L.Saboungi and P.Cerisjer : Met. Trans. 10B(1979), 613 .

(46) S.Otsuka : Trans. JIM, 26(1985), 167.

(47) N.Ohtomo and K.Arakawa : J.Phys. Soc. Japan, 51 (1982), 1282.

(48) 文献(5), p.7.

(49) W.H.Young : Liquid Metals, Conf. Ser. No.30, Inst. Phys., Bristol, (1977), 1.

(50) N.W.Ashcroft and D.Stroud: Solid State Phys., 33 (1978), 1.

(51) J.Hafner : Phys. Rev. A, 16(1977), 16 ; J. Non-Cryst. Solids, 61 \& 62(1984), 175.

(52) S.K.Lai, M.Matsuura and S.Wang: J.Phys. F, 13 (1983), 2033 ; S.Wang and S.K.Lai : ibid., 10(1980), 445.

(53) I.Yokoyama, M.J.Stott, I.H.Umar and W.H.Young : Liquid Metals, Conf. Ser No.30, Inst. Phys., Bristol, (1977), 95.

(54) I.Yokoyama, M.J.Stott, M.Watabe, W.H.Young and M.Hasegawa : J. Phys. F, 9(1979), 207.

(55) A.P.Copestake, R.Evans, H.Ruppersberg and W. Shirmacher : J. Phys. F, 13(1983), 1993 ; J.Non-Cryst. Solids, 61 \& 62(1984), 231.

(56) J.Hafner, A.Pasturel and P.Hicter : Z. Metallkde., 76 (1985), 432.

(57) W.Shirmacher : J. Non-Cryst. Solids, 35(1980), 1301.

(58) J.R.Franz, F.Brouers and C.Holzhey : J. Phys. F, 12 (1982), 2611. 
(59) S.Takeuchi, O.Uemura and S.Ikeda : The Properties of Liquid Metals, Ed. by S.Takeuchi, Taylor \& Francis, London, (1973), 489.

(60) A.B.Bhatia and W..H.Hargrove : Lett. Nuovo Cim., 8 (1973), 1025 ; Phys. Rev., B10(1974), 3186.

(61) A.B.Bhatia, W.H.Hargrove and N.H.March: Phys. Rev., B9(1974), 435 ; A.B.Bhatia and V.K.Ratti : Phys. Lett., 51A(1975), 386 ; J. Phys. F, 6(1976), 927.

(62) A.B.Bhatia : Liquid Metals, Conf. Ser. No.30, Inst. Phys., Bristol (1977), 21.

(63) K.Hoshino and W.H.Young: J. Phys. F, 10(1980), 1365.

(64) P.Gray, S.Tamaki, Y.Tsuchiya and N.E.Cusack : Phys. Chem. Liquids, 9(1980), 307.

(65) P.Gray: J. de Phys., 41(1980), C8-577.

(66) S.Tamaki, T.Ishiguro and S.Takeda : J.Phys. F, 12 (1982), 1613.

(67) S.Tamaki, Y.Waseda, S.Takeda and Y.Tsuchiya : J. Phys. F, 12(1982), 1109.

(68) S.Takeda, T.Akasofu, Y.Tsuchiya and S.Tamaki : J. Phys. F, 13(1983), 109.

(69) S.Matsunaga, T.Ishiguro and S.Tamaki : J. Phys. F, 13(1983), 587

(70) K.Hoshino : J.Non-Cryst., 61 \& 62(1984), 529 ; J. Phys. F, 13(1983), 1981, L189.

(71) A.B.Bhatia and R.N.Singh : Phys. Chem. Liquids, 13 (1984), 177.

(72) A.B,Bhatia : Phys. Chem. Liquids, 13(1984), 241.

(73) T.Itami, T.Wada and M.Shimoji : J. Phys. F, 12(1982), 1959 ; T.Itami et al. : ibid., 13(1983), 1225 : ibid., (1984), 427 ; J. Non-Cryst. Solids, 61 \& 62(1984), 1383 ; Shimoji et al., ibid., 61 \& 62(1984), 135.

（74）例えば, 吉沢 徵: 日本物理学会誌, 38(1983), 845.

(75) 浅井滋生, 岡本徹夫, 赫翼成, 鞭峳: 鉄と鋼, 68 (1982), 426.
（76）加藤嘉英, 中西恭二, 野崎 努, 鈴木健一郎, 江見俊彦: 鉄と鋼, 68(1982), 1604.

（77）渡辺吉夫, 赫 翼成, 浅井滋生, 鞭厳 : 鉄と鋼, 69 (1983), 1160.

（78）日本金属学会会報：特集・非晶質金属の特性, 15(1976), 151-206.

（79）日本金属学会会報:特集・準結晶の構造と物性, 25 (1986), 98-132

（80）新宮秀夫, 石原慶一：鉄と鋼，69(1983), 1087

（81）新宮秀夫，石原慶一：日本金属学会会報, 25(1986), 16

(82) J.B.Suck, J.H.Perepezko, I.E.Anderson and C.A.Angel: Phys. Rev. Lett., 47(1981), 424 ; その他は文献(2), p.230 参照.

（83）好村滋洋: 固体物理, 19(1984), 711; S.Komura et al., Jap. J. Appl. Phys. 22(1983), 31 ; Physica, 120B(1983), 122

(84) H.Furukawa : Prog. Theor. Phys., 59(1978),1072; Phys. Rev. Lett., 43(1979), 136 ; Phys. Rev., 23A(1981), 1535 ; Physica, 123A(1984), 497.

(85) M.H.Cohen and G.S.Grest:Phys. Rev. B20(1979), 1077.

(86) M.Cyrot: J. de Phys., 41(1980), C8-107.

(87) P.Desre, M.Shimoji, A.Pasturel and P.Hicter : Phys. Lett., 96A(1983), 299,

(88) L.Sjögren : Phys. Rev. A, 33(1986), 1254.

(89) G.Adam and J.H.Gibbs : J.Chem. Phys., 43(1965), 139.

(90) J.M.Hutchinson and A.J.Kovacs : J.Polymer Science, 14(1976), 1575.

(91) J.Kawamura and M.Shimoji : J. Non-Cryst. Solids, in press.

(92) H.Haken : Synergetics, 2nd. ed., Springer, Berlin, (1978), 1

(93) B.Billia, A.Steinchen, A.Sanfeld and L.Capella : J. Non-Equilib. Thermodyn., 7(1982), 221. 